\title{
Lydnadsplikt och samvetsfrihet i medeltida biktlitteratur
}

\author{
Biörn Tjällén
}

Vid påsken år 1310 förnekade Botulf att brödet och vinet förvandlades till Kristi kropp och blod. Några år tidigare hade han fått göra bot för samma kätterska uppfattning, men nu var han alltså tillbaka med de andra bönderna i Gottröra socken, i kön på väg mot altaret där prästen delade ut hostian. Där möttes han av en direkt fråga: Trodde han nu att brödet var Kristi sanna lekamen? Det gjorde han inte, och därmed hade han för andra gången förnekat sakramentet. Brevet som senare förkunnade domen mot Botulf som kättare (hereticum iudicamus!) berättar något om hur han utvecklade sina skrupler inför eukaristin: Om det nu förhöll sig så att det var Kristi kropp som delades ut och åts upp, skulle Gud då inte hämnas? Botulf ville lyda Gud på andra sätt, men Kristi kropp ville han inte äta. I kyrkans ögon var det mycket allvarligt eftersom det innebar att Botulf nu var återfallen (prolapsus) i sitt tidigare kätteri. Och denna gång ändrade han inte uppfattning, ens när han i fängsligt förvar hotades med bålet. ${ }^{1}$

Forskningen har naturligtvis intresserat sig för domen mot Botulf. Äldre studier frågade till exempel var han fick sina kätterska idéer - var han inspirerad av kontinentens katarer, ${ }^{2}$ eller skulle han ses som en representant för ett svenskt bondförnuft som förhöll sig kritiskt till den komplicerade läran om transsubstantiationen ${ }^{3}$ Nyare forskning har undersökt hur processen mot Botulf förhöll sig till samtida svensk och kanonisk rätt, ${ }^{4}$ och rentav diskuterat Botulfs egna diskursiva taktiker för att undvika upptäckt och straff för kätteri. ${ }^{5}$ En annan fråga är viktigare för denna volym: Varför höll Botulf fast 
vid sin avvikande uppfattning om eukaristin, trots att han visste att den skulle få allvarliga, kanske dödliga, konsekvenser? Dombrevet, som innehåller allt vi vet om målet, går inte närmare in på Botulfs överväganden. Men det rapporterar vad han svarade på tal om bålet, nämligen att "den elden går över på kort tid". ${ }^{6}$ Det fanns alltså en annan, evig eld, som Botulf fruktade mer än det bål som utdömdes av kyrkliga och världsliga myndigheter. Det är denna motsättning mellan plikten att lyda samhällets auktoriteter och plikten att lyda Gud - i formen av det egna samvetet - som står i fokus i detta kapitel.

Det är lätt att uppfatta domen mot Botulf - Sveriges enda kända kätteriprocess - som ett paradigmatiskt exempel på kyrklig maktfullkomlighet, en tragisk konsekvens av stelbent dogmatism inför en fritänkande eller kanske själsförvirrad individ. Det är naturligtvis riktigt att se det så. Men den här artikeln föreslår att förhållandet mellan Botulf och kyrkan också var mer komplicerat. Kättardomen motiverades av kyrkans dogmatiska försvar av transsubstantiationsläran. Men Botulfs motstånd kan ses som en konsekvens av en annan princip, som även den lärdes ut av kyrkan: att man skall följa samvetet före kyrkliga och världsliga auktoriteter. Följande sidor handlar inte specifikt om Botulf - mycket har redan forskats om den processen utan redogör för ett idé- och kyrkohistoriskt sammanhang där denna och liknande episoder blir mer begripliga. Kapitlet undersöker hur frågan om lydnadsplikt och samvetsvägran behandlades i medeltida moralteologi och hur sådana teorier omsattes i praktiken i den medeltida själavården. Frågan har tangerats tidigare men är av en sådan komplexitet och betydelse att den förtjänar fortsatt behandling. ${ }^{7}$ Som ett exempel ur den lärda diskursen om samvetet fokuserar redogörelsen nedan på Thomas av Aquino (d. 1274), som får representera en inflytelserik högmedeltida uppfattning om samvetet i ett fält där det förvisso även fanns andra idéer. ${ }^{8}$ För att fånga hur sådana uppfattningar sedan praktiserades i själavården diskuteras ett senmedeltida exempel - författat av den populäre Antoninus av Florens (d. 1459) - ur den litteratur som producerades för att hjälpa de präster som verkade som biktfäder och därmed moraliska lärare för medeltidens människor. Med hjälp av denna litteratur kan vi belysa de föreställningar om 
samvetet som kyrkan förmedlade och diskutera hur man tänkte sig att konflikter mellan individens samvete och kyrkliga och världsliga auktoriteter skulle behandlas. Med Thomas och Antoninus som exempel på samvetets teori och praktik säger vi inget med säkerhet om just Botulfs uppfattningar i frågan; det är inte möjligt att avgöra vad en lekman i det tidiga 1300-talets Sverige fick höra av sin präst om samvetet och Antoninus skrev dessutom långt efter Botulfs levnad, även om hans texter ofta bygger på äldre förlagor. Men det viktiga i det här sammanhanget är som sagt inte den specifika episoden om Botulf, utan den övergripande idéhistoriska kontext som kan hjälpa att göra sådana episoder lättare att förstå.

\section{Samvetets teori}

Det var inte bondförnuft, och knappast självbevarelsedrift, som sade att man hade en plikt att lyda sitt samvete även när överheten önskade något annat. Uppfattningen var sanktionerad av kyrkans lärare. Thomas av Aquino uttryckte sig tydligt när han förklarade samvetet suveränt:

Det rätta samvetet är bindande inte bara i det avseendet att den som inte följer det hamnar i synd, utan även så att den som följer det är fri från synd oavsett hur mycket han kommer i konflikt med prelaters befallning. ${ }^{9}$

Principen var alltså klar: den som följer sitt samvete syndar inte, även om hon handlar emot vad kyrkan befallt. Men denna principiella samvetsfrihet komplicerades och begränsades av ett antal förhållanden. För det första så talar Thomas här om det rätta samvetet (conscientia recta). Som vi skall se så menade han att samvetet också kunde vara felande (conscientia erronea). För det andra så bör man notera att Thomas talar om förhållandet mellan samvete och synd, inte om samvete och skuld i lagens mening. Att följa sitt samvete och därmed vara syndfri inför Gud var inte detsamma som att slippa rättsliga sanktioner. För det tredje så omfattades samvetet av en särskild 
institutionell praktik, botsakramentet, där individens rannsakning av det egna samvetet vägleddes av en präst. Precis som frågor om brott mot kyrkans lagar behandlades i ett offentligt juridiskt forum (kallat forum externum eller forum judiciale), så skedde rannsakningen av samvetet efter synder i botsakramentets inre forum (forum internum), även kallat samvetets forum (forum conscientiae). ${ }^{10}$ Men trots dessa teoretiska och praktiska begränsningar för samvetsfriheten så var själva principen alltså klar: samvetet var suveränt. Men vad menade man egentligen med "samvetet", och varför tillskrev man detta en sådan betydelse? Vilka uppfattningar fanns bland kyrkans lärda, och vad lärde man ut till lekmännen?

Det lades mycket energi på att definiera samvetet. Ett skäl till det var att frågan antyddes i Petrus Lombardus (d. 1160) Sentenser, som användes som lärobok i teologiska studier och därför tenderade att sätta agendan för många diskussioner. Petrus diskuterade hur det kommer sig att människan ibland vill göra det onda och citerade i det sammanhanget kyrkofadern Hieronymus (d. 420). Hieronymus hade å ena sidan hävdat att det i människan fanns en gudomlig gnista - en vilja till gott och en avsky inför det onda - som inte kunde utsläckas, ens i bröstet på en brodermördare som Kain. Det är denna oförstörbara samvetsgnista, synderesis, som hjälper henne att urskilja när hon syndat. Men på ett annat ställe sade Hieronymus tvärtom, att det finns människor som helt lagt samvetet åt sidan. Om man ställde dessa två passager mot varandra så framstod samvetet som något motsägelsefullt, bergfast och flyktigt på en och samma gång. Många medeltida lärda kommenterade de problem kring samvetet som togs upp i Sentenserna. Den lösning som blev utgångspunkt för den vidare diskussionen var att samvetet bestod av två olika delar, synderesis och conscientia. Uppdelningen mellan dessa två aspekter innebar olika saker för olika författare, men där synderesis i allmänhet uppfattades som en ofelbar och oförstörbar instans som gav allmänna principer om rätt och fel, så betraktades conscientia som en instans där sådana allmänna principer tillämpades. ${ }^{11}$

Thomas av Aquino kommenterade själv Sentenserna men diskuterade samvetet även i sin stora handbok till teologin, Summa theologiae, 
samt i de "omdebatterade frågor" som citerades ovan och som även de var ett resultat av hans undervisning. I den senare texten ägnar han en questio vardera åt synderesis och conscientia. Det mesta i dessa questiones har mindre betydelse för vår fråga om förhållandet mellan samvetet och samhällets auktoriteter. Thomas definierar till exempel samvetet, i dess två olika former, i de termer som vid tiden användes för att beskriva människans egenskaper - synderesis är en habitus (en vana eller karaktärsdisposition) och inte en potentia (förmåga). Conscientia, å andra sidan, är en intellektuell handling (actus), som tillämpar synderesis i konkreta situationer. Thomas ger ingen allmän beskrivning eller lista på de principer som förmedlas av synderesis, men ett fătal exempel i texten anger att det rör sig om föreskrifter av mycket allmän art, till exempel att man bör böja sig för Guds vilja. Lydnadsproblematiken utreds inte med någon större konkretion $\mathrm{i}$ dessa questiones, men här presenteras ändå den allmänna föreställningen om samvetets suveränitet. Thomas frågar om synderesis kan ta miste. Svaret är att de allmänna principer som ges av synderesis inte kan ta fel men att conscientia, som alltså tillämpar dessa principer, kan göra det. Thomas frågar vidare om man är tvingad att lyda samvetet, och om denna lydnadsplikt gäller även ett samvete som felar. Om samvetet har rätt så tvingar det naturligtvis till efterlevnad i alla sammanhang (man kan ju inte bortse från dess maningar utan att synda). Men även ett samvete som tar fel förpliktar (det vore synd att gå emot vad man i god tro trodde var det rätta). Men kravet att lyda ett felande samvete gäller naturligtvis inte för alltid, eftersom missuppfattningen kan klarna så att det felande samvetet läggs åt sidan. ${ }^{12}$

Thomas syn på det felande samvetet är värt att granska närmare här eftersom han själv använde den som förklaring på det problem som inledde denna artikel, alltså kätteri. Synderesis "knotar mot synden och vänder oss till det som är gott", med ofelbara men också mycket allmänna principer som conscientia alltså tillämpar i specifika situationer. Olyckligtvis inträffar ibland förnuftsmässiga misstag i dessa tillämpningar - oriktiga slutledningar eller antaganden - vilket innebär att samvetet leder fel. Vi har då att göra med ett conscientia erronea. ${ }^{13}$ Enligt Thomas, som i passagen nedan argumenterar emot 
uppfattningen att synderesis kan utslockna, beror kätteri på just sådana misstag vid tillämpning av den oförstörbara samvetsgnistans principer. Problemet med kättarna är inte att de inte följer sitt samvete, utan att deras samvete tagit miste om viktiga detaljer:

[...] hos kättarna tillrättavisar samvetet (conscientia) inte deras otrohet på grund av ett fel i deras högre förnuft, som får till följd att synderesis omdöme (iudicium) inte tillämpas i det specifika fallet. Ty synderesis allmänna omdöme finns kvar i dem: de tror ju att det är dåligt att inte tro på något som har sagts av Gud. Men genom det högre förnuftet tar de fel, då de inte tror på att detta något har sagts av Gud. ${ }^{14}$

Thomas kan tyckas onödigt spetsfundig. Men den skolastiska typ av resonemang som han här får representera var inte en isolerad universitetsprodukt. Det upprepades i den litteratur som hjälpte prästerna i själavården och som därmed lärde medeltidens kristna vad samvetet var och hur det skulle hanteras. Främst skedde detta i samband med botsakramentet eller skriftermålet, alltså i "samvetets forum”. Från år 1215 skulle alla vuxna - årligen vid fastan, vid andra särskilda tillfällen, eller när samvetet krävde det - rannsaka sig och bekänna synderna inför sin präst i hopp om avlösning. ${ }^{15}$ Utvecklingen understöddes av en rik litteratur av biktmanualer och moralteologiska handböcker till hjälp för de präster som hade att hjälpa sina biktbarn till full bekännelse. Denna litteratur utgick naturligtvis från befintliga moralteologiska arbeten, till exempel från Thomas, liksom från samlingar av kyrkorätt, men för oss ändå närmare den praktiska själavården och det som ovan kallades samvetets institutionella praktik. Två huvudsakliga genrer kan identifieras i denna litteratur för bikten: moralteologiska "summor" som sammanfattade vetande från olika fält med bäring på själavården (allt från syndens natur och människans olika själsförmågor till förhållandet mellan olika typer av lagar behandlas i dessa texter), samt mindre omfattande men mer praktiskt orienterade manualer till hjälp för den präst som skulle administrera botsakramentet. ${ }^{16}$ 
Den präst i det medeltida Sverige som ville få råd för arbetet med själavården, och inte saknade medel för att köpa böcker, hade åtskilligt att läsa. Men det är inte meningsfullt att försöka urskilja någon specifik" "svensk" litteratur på detta område. Svenska handskrifter från tiden före boktryckarkonsten, till exempel från samlingen i Vadstena, innehåller moralteologisk litteratur av det slag som användes i hela Europa. ${ }^{17}$ Från 1400-talets slut började den moralteologiska handbokslitteraturen också att tryckas, och sådana titlar spreds snabbt även till svenska bibliotek. Exempel ur de två genrer som nämndes ovan är den Summa theologica moralis och den manual för botens sakrament, Confessionale, som båda författats av Antonio Pierozzi (d. 1459), mer känd som Florens helgonförklarade ärkebiskop, S:t Antoninus. Dessa titlar återfanns i Vadstena och andra svenska kloster, i händerna på andra svenska klerker och synbarligen även bland samlingar som hört till lekmän. ${ }^{18}$ Med tanke på just dessa texters stora popularitet och spridning i Europa i övrigt är det knappast förvånande att vi återfinner dem även i Sverige. ${ }^{19}$

Summa theologica moralis består av tre volymer och den första av dessa behandlar bland annat människans själsförmågor. Under rubriken De potentia intellectiva (om förståndsförmågan) finns två kapitel som berör samvetet i enlighet med den uppdelning som blivit den brukliga, ett om synderesis och ett om conscientia. Antoninus följde sin ordens lärare, Thomas, och slog fast synderesis essens (dess quidditas) som "en medfödd karaktärsdisposition ( habitus), eller ett medfött ljus, vars gärning eller ämbete det är att avhålla människan från det som är dåligt med knot mot synden, och som leder mot det som är gott". I relativ korthet beskriver han sedan denna dispositions ofelbarhet (impeccabilitas) och oförstörbarhet (inextinguibilitas). ${ }^{20}$ I jämförelse med Thomas långa redogörelser av argument för och emot olika uppfattningar, vilka passade för att få teologistudenter att se olika sidor av ett ämne, så är Antoninus framställning i regel mer kortfattad och handfast. Han inleder ofta sina paragrafer med att slå fast vad som gäller, för att sedan presentera de huvudsakliga argumenten till stöd. I Thomas efterföljd slår han fast att conscientia tillämpar kunskap från synderesis i specifika fall. Hans påföljande 
beskrivning av vad samvetet gör har direkt tillämpning på botsakramentets praktik: samvetet vittnar, anklagar, och binder eller löser. Även hans beskrivning av hur samvetet kan fela, hur och när det förpliktar, och hur det skänker tröst när det är gott men det motsatta när det är dåligt, har konkret betydelse för biktfaderns uppgift att vägleda sina botgörare till fullständig bekännelse och ånger. Det gäller också det avsnitt om scrupolositas - den överdrivna och skadlig samvetsängslan som även andra senmedeltida författare uppfattade som ett problem - som avslutar Antoninus redogörelse för samvetet. ${ }^{21}$

Det är inte troligt att varje sockenpräst tillägnat sig all den kunskap som förmedlades av böcker som Summan, och naturligtvis än mindre att allt förmedlades från dem till lekmännen. Vi vet en del även om hur svenska lärda i det tidiga 1300-talet resonerade om sakrament som boten, ${ }^{22}$ men det är svårare att säga vad en vanlig sockenpräst eller en lekman som Botulf specifikt snappat upp. Vad som däremot förenade både lekt och lärd under perioden var att de kom i kontakt med den själavårdspraktik där samvetet stod i centrum. Det var också där, i mötet mellan kyrkans normer och medeltida människors vardag, som eventuella konflikter mellan samvetet och samhällets auktoriteter kunde identifieras.

\section{Samvetets praktik}

Thomas av Aquino noterade att samvetets suveränitet kunde få praktiska konsekvenser för relationen mellan överhet och undersåtar, till exempel i fallet med kätteri. För en vidare förståelse av varför det förhöll sig på det sättet är det nödvändigt att hänvisa även till texter som inte specifikt behandlar samvetet, utan snarare sätter både lydnaden och lagen i förhållande till en av Gud inrättad ordning. Kravet att lyda Gud var absolut, vilket innebar att kravet att lyda överheten hade vissa begränsningar:

Människan står under Gud, absolut och i allt, både vad gäller det inre och yttre, och är därmed skyldig honom lydnad i allt. Undersåtar står emellertid inte under sina överordnade i allt, utan i vissa ting 
inom vissa gränser. I dessa ting är de [överordnade] att betrakta som mellanhand mellan Gud och undersåtarna. Vad gäller annat står de [undersåtarna] emellertid direkt under Gud, som undervisar dem genom den naturliga eller nedskrivna lagen. ${ }^{23}$

Mänskliga påbud är alltså underordnade gudomliga, och mänskliga auktoriteter giltiga bara inom de begränsade områden där de är satta att råda. I frågor om lag och rätt så innebar det att mänsklig lag var lag i egentlig mening endast om den sammanföll med Guds eviga lag - vi är med andra ord långt ifrån den positiva rättsuppfattning som är den vanliga i moderna samhällen. Men Thomas angav även andra, mer politiska och formella, kriterier för bedömningen av mänskliga lagars giltighet: de skulle utfärdads av en auktoritet som hade rätt att göra det; de skulle syfta till det allmänna bästa; de skulle fördela sin börda rättvist över den politiska gemenskapen. ${ }^{24}$ Alla dessa bedömningsgrunder vävs in när Thomas utreder förhållandet mellan samvetet och lagen i frågan "om den mänskliga lagen förpliktar människan i samvetets forum”, alltså i botsakramentet samvetets institutionella praktik - där biktfadern var satt att hjälpa sitt biktbarn att identifiera och bekänna sina synder. Thomas svar är att rättvisa lagar förpliktar samvetet, medan orättvisa lagar inte gör det. Lagen är rättvis när den följer Guds bud samt uppfyller de politiska och formella krav som nämndes ovan. Annat är det när en mänsklig lag eller befallning går stick i stäv mot gudomlig lag (contra legem divinam). Samvetet står över en sådan orättfärdig lag, eftersom samvetets omdöme per definition uppfattas som utgående från Guds påbud (iudicium conscientiae maxime dependet ex divinis mandatis). ${ }^{25}$

För Thomas är det alltså uppenbart hur man skall ställa sig till exempel när en tyrann påbjuder avgudadyrkan eller något annat som går rakt emot Guds bud, för "man måste lyda Gud mer än människor" (Apg 5:29). Mer pragmatiskt förhåller han sig till påbud som är orättvisa på andra, ovan nämnda politiska eller formella, grunder. Gud har inte givit överheten rätt att förtrycka folket med orättvisor. Orättfärdiga lagar har därför ingen tvingande kraft i någon absolut mening utan kan motstås med gott samvete. Men Thomas är ingen 
politisk revolutionär. Han antyder att orättvisa lagar av denna andra typ endast bör trotsas om det kan göras utan att orsaka skandal eller värre skada ( $s i$ sine scandalo vel maiori detrimento resistere possit). ${ }^{26}$

Thomas principiella uttalanden var kanske klara. Men själavårdslitteraturen visar att det under medeltiden kunde vara lika komplicerat som idag att säkert veta vad som var rätt och fel. Hur skulle man till exempel veta att det var det rätta samvetet som manade och inte bristfälliga, vilseledande tillämpningar av denna gudomliga gnista? Annorlunda uttryckt: Hur skulle man fatta välgrundade, moraliskt säkra, beslut i svåra frågor? Dubier kring en handlings eventuella syndfullhet orsakades inte minst av att olika föreskrifters tillämpbarhet i enskilda fall kunde diskuteras - vad göra i de fall där varken Bibel eller påvebullor gav något klart svar, och där kyrkans lärde hade motstridiga uppfattningar?

Moraliskt beslutsfattande uppfattades som ett fält med egna kunskapsteoretiska förutsättningar. Thomas och andra tog till sig Aristoteles uppfattning att olika kunskapsområden medgav olika precision. I spekulativa discipliner som teologi och matematik var eviga sanningar möjliga, men praktiska och kontingenta fält som politik och etik tillät ingen sådan absolut säkerhet. Moraliskt beslutsfattande innebar alltså alltid vissa risker. Det utvecklades tekniker för att hantera sådana risker, och de förändrades under den medeltida perioden. Enligt den högmedeltida regula magistralis var man skyldig att riskminimera. I tveksamma fall skulle man välja det moraliskt säkraste (in dubiis tutior pars est eligenda), alltså det handlingsalternativ som innebar minst risk för synd. Denna "tutiorism" innebar svårigheter i praktiken. Borde man undvika att överhuvudtaget göra affärer, eftersom det nog var säkrast att låta bli? Och hur visste man egentligen vad som var säkrast? Strängt tolkad innebar regeln praktiska hinder och krav på bedömningsförmåga som nog översteg vad de flesta människor och deras rådgivare klarade $a v .{ }^{27}$ Med sådana förhållningsregler för moraliskt beslutsfattande så är det lätt att förstå att mer samvetsömma individer riskerade att plågas av ständiga skrupler - scrupolositas med ett lika ständigt behov av bikt som resultat. 
En praxis som utvecklades för att hantera sådana svåra val var att välja det handlingsalternativ som hade stöd av flest experter. Men utöver de svårigheter som redan nämnts så medförde den kyrkopolitiska utvecklingen under senmedeltiden att en sådan modell var svår att upprätthålla. Under schismen - när kyrkan i perioder under slutet av 1300-talet och början av 1400-talet splittrades i olika obedienser under konkurrerande påvar - kunde grupper av kyrkliga experter stå emot varandra av politiska skäl. Hur skulle man som individ i en sådan situation veta vilken påve man skulle lyda för att inte själv bli evigt fördömd? Jean Gerson (d. 1429), som själv var aktiv i försöken att få ett slut på schismen men också var en förnyare inom själavården, förordade mindre omständliga krav vid moraliskt beslutsfattande. Enligt Gerson så behövde beslutsfattare och deras rådgivare inte genomsöka och väga hela fältet av experter i en viss fråga. De kunde nöja sig med att det fanns en mindre grupp auktoriteter som gav stöd för den uppfattning som de själva ansåg förnuftig, utan samvetsoro. För Gerson var det en hållning som kunde tillämpas även utanför den omedelbara kontexten av schismen, till exempel i affärslivet. En god kristen kunde handla med gott samvete även om det inte gick att slå fast med någon absolut säkerhet att den moraliska kursen var den rätta. I kontingenta frågor som dessa fick man nöja sig med vad han kallade en moralisk säkerhet (certitudo moralis). ${ }^{28}$

Om Antoninus Summa fungerade som en handbok till olika teoretiska frågor av relevans för själavården, till exempel om samvetet, så ger hans biktmanual, känd som Confessionale eller Defecerunt, snarare en inblick i de institutionella praktiker som utvecklades kring detta inre forum. Både svårigheten i moraliskt beslutsfattande och konflikter mellan samvetet och världsliga auktoriteter berörs. I inledningen av Confessionale beskriver Antoninus skriftermålet som ett sökande, där biktbarnet utforskar sitt samvete med biktfaderns hjälp. ${ }^{29}$ Tillsammans söker man synder så att biktbarnet kan ångra dem och göra fullständig bekännelse. Biktfadern har en viktig roll i denna introspektion. "Samvetets forum" är förvisso avskilt från offentligheten. Men det är ingen plats för individuellt grubbel eller för 
subjektiv värdering av egna överträdelser, utan ett fält där det krävs prästerlig vigning för att binda eller lösa samt en stor portion expertis för att avgöra vilket. Antoninus betonar att biktfadern måste ha nödvändiga kunskaper, "så att han kan skilja mellan synd och inte synd, och mellan dödlig synd och förlåtlig, samt veta att tveka i sådant som är tveksamt så att han kan vända sig till någon mer erfaren". ${ }^{30}$

Antoninus skisserar biktfaderns kunskapsprofil. Denne måste vara bekant med kyrkans lag, eftersom vissa saker är synd emedan de bryter mot denna. Annat är synd för att det är dåligt i sig, oavsett om det innebär lagbrott. Det gäller de sju huvudsynderna, till exempel högmod, lusta eller frosseri. Biktfadern förväntas vara bekant med dessa huvudsynders olika typer av uttryck (otukt är en typ av lusta och dryckenskap en typ av frosseri) och i mindre komplicerade fall kunna avgöra när dessa skall klassas som dödliga och när de är förlåtliga. ${ }^{31}$ Antoninus är medveten om att kunskaperna inom prästerskapet kan variera. Om biktfadern själv är biskop eller annan högre prelat så är förväntningarna på hans förmåga att avgöra sådana saker högre än om det rör sig om en vanlig sockenpräst. Men Antoninus betonar att biktfadern skall akta sig för att slå fast att något är dödlig synd när han själv inte är säker. I vissa frågor finns det ju olika uppfattningar bland lärda doktorer om vad som är tillåtet och inte.

Ett av Antoninus exempel på sådana osäkra fall måste ha legat nära till hands för den som handskades med själavård i renässansens Italien: Var handel med andelar i den florentinska statsskulden (emptionem iurium montis florentiae) att betrakta som otillåtet ocker? Här, kommenterar Antoninus, fanns olika uppfattningar för och emot, och i sådana tveksamma fall skulle biktfadern rekommendera det säkraste (quod tutius est); han bör alltså säga till sitt biktbarn att avstå från sådan handel. Men, tillägger han, biktfadern bör inte fördöma den som väljer att ändå bedriva sådan handel, eller den som anser det riktigt att göra det. Inte heller bör han förneka avlösning till någon som är av en sådan uppfattning. ${ }^{32}$ Denna generösa tolkning av tutiorismen som förmedlas genom Confessionale återspeglar vad Antoninus skriver i sin Summa. Där betonar han att maximen att välja det säkraste alternativet (in dubiis tutior via est eligenda) skall 
förstås som ett råd och inte som en befallning. I annat fall, kommenterar han, borde fler gå i kloster eftersom klosterlivet är moraliskt säkrare än livet ute i världen, ett utfall som han tycks mena faller på sin egen orimlighet. Istället betonar Antoninus att det inte skall förstås som ett tvång att välja den säkrare (tutiorem) vägen, utan går bra att välja en annan, som fortfarande är säker (tuta). ${ }^{33}$ Men även här kan samvetet - och i detta fall biktfaderns samvete snarare än biktbarnets - spela en avgörande roll. Om biktfaderns samvete, trots experternas delade meningar, tveklöst håller fast vid att den företeelse som diskuteras är en dödlig synd så måste han rätta sig efter det, annat vore att själv synda. ${ }^{34}$

Arbetet som biktfader ställde krav även på kunskaper utöver det kyrkorättsliga och moralteologiska området. Människor syndar ju i olika typer av sociala, politiska och ekonomiska relationer, av olika slag beroende på individens ställning och verksamhet. Biktfadern måste alltså vara bekant med olika levnadsförhållanden och hur de regleras. Specifika frestelser drabbar den som är köpman eller domare. Makar utsätts för moraliska risker som inte drabbar den som lever i celibat, och vice versa. Specifika levnadsförhållanden ställer därför krav på specifik kunskap hos biktfadern. Antoninus påtalar att den som är biktfader åt till exempel en världslig furste kommer att ställas inför dilemman som hör till aktiviteter typiska för denna kategori:

Biktfadern bör kunna skilja mellan olika synder och mellan olika typer av syndare. Sålunda behöver biktfadern veta om det som biktbarnen berättar för honom är synd eller ej, till exempel när det gäller furstar om deras krig eller skatter är lagliga eller ej, eller om de avtal som de upprättar är lagliga eller ej. ${ }^{35}$

Ovanstående citat antyder att kraven på kunskaper i vida fält var höga, åtminstone i teorin. Som tur var fanns det hjälp att få. Antoninus Confessionale innehåller omfattande frågeformulär, med frågor anpassade för olika kategorier av biktbarn. Med dessa får biktbarnet hjälp att genomsöka det egna samvetet. Furstar, advokater, studenter, hantverkare, bönder och andra behandlas på dessa sidor med lämpliga 
frågor. Har bonden varit svekfull mot jordägaren, till exempel genom att inte så eller plocka frukt som han borde, eller genom att slita ut dennes djur? Och tror bonden uttryckligen på de heliga mysterier som firas i kyrkan, till exempel Kristi människoblivande, lidande och uppståndelse $?^{36}$ Denna senare exempelfråga liknar den som Botulf fick om transsubstantiationen, på väg mot altaret i Gottröra, alltså den som fick honom att återfalla i sitt tidigare kätteri. Vi vet inte, men det förefaller rimligt att det i själva verket var innan eukaristin, $i$ samband med bikten - i arbetet med att genomsöka Botulfs samvete efter synder - som den besvärliga frågan först hade dykt upp.

Men även furstar fick alltså skäl att rannsaka sitt samvete, efter synder som klängt sig fast i samband med styret. De frågor om krig och beskattning som nämndes ovan, och som Antoninus använde som exempel på biktfaderns behov av specialistkompetens anpassad för det specifika biktbarnet, återkommer i hans frågeformulär för världsliga herrar. Om fursten har pålagt olagliga skatter så skall det betraktas som rån (rapina) av undersåtarna. Om han har startat ett orättfärdigt krig så är han skyldig att betala för skadegörelsen. ${ }^{37}$ Men vilka skatter och vilka krig är orättfärdiga? Här krävdes det onekligen expertis. För frågor om skatter hänvisar Antoninus till sin egen utförligare utredning av frågan i Summa. Där sammanfattar han olika expertutlåtanden och kriterier som den världslige furstens biktfader kunde använda för att bedöma om dennes skatter var rättfärdiga, eller om de skulle betraktas som rån och dödlig synd. Men Antoninus gör klart att även undersåtarna löper moraliska risker i samband med beskattning. Frågan om man som undersåte skall betala den skatt som krävs av fursten blir i själva verket en konkret manifestation av hur plikten att lyda överheten ställs emot och måste underordna sig plikten att lyda samvetet. Den som frivilligt bidrar genom att betala sin skatt till finansieringen av ett orättfärdigt ändamål - till exempel ett orättfärdigt krig - begår själv en synd. Vid sådana tillfällen kan man, enligt Antoninus och de experter som han tar stöd av, med gott samvete undvika att betala, men bara om det är möjligt att göra det utan att begå mened eller synda på annat vis för att undkomma skatten. Att underlåta att betala en laglig skatt är däremot att betrakta 
som stöld, och en dödlig synd. Men precis som Thomas, som bidragit med flera argument till texten, så manar Antoninus till en pragmatisk hållning. Det faktum att det inte är en synd att vägra att betala skatt till exempel till den furste som inte beskyddar eller ger rättvisa åt sina undersåtar skall inte ses som en handlingsrekommendation. Upprepade gånger betonar han att den som i sådana fall väljer att inte betala den utkrävda skatten är utan synd bara om hon kan göra det utan att ställa till med oro eller skandal (non peccant si tamen fiat hoc sine scandalo $).{ }^{38}$

Precis som i fallet med furstens skatter så motsvarades de korta frågorna om hans krig i Confessionale av en utförligare behandling av temat i Summa. Även här framgår att det inte bara är fursten, som befaller om krig, utan även soldaten, som lyder, som har plikt att rannsaka sitt samvete så att synd kan undvikas eller, om det redan är för sent för det, bekännas. Den grundläggande frågan var naturligtvis om kriget var rättfärdigt (justum). Undersåtar och överhet hade här att förhålla sig till expertisens uppfattning, men med olika grader av ansvar. ${ }^{39}$

Om någon är undersåte till en krigförande [herre] och följer honom i kriget, och vet att dennes krig är orättfärdigt, då kan han genom att ha följt inte hållas fri från synd eller från att ersätta uppkomna skador [...] men om det efter råd från experter fortsatt råder tvivel om krigets rättfärdighet, då är en sådan [undersåte] ursäktad, eftersom han i tveksamma fall måste lyda [sin herre]. Men herren ursäktas inte. ${ }^{40}$

Skatter, krig och plikt att lyda överheten var verklighet i det medeltida samhället, men det var också plikten att lyda samvetet. Vi vet naturligtvis inte hur vanligt det var att samvetsgranna präster, som biktfäder för hög och låg, tog upp och hanterade dilemman som de ovanstående, där den ena plikten ställdes mot den andra. Men den litteratur där dessa frågor behandlades var spridd, och den var tänkt att hjälpa klerkerna i den själavård som omfattade alla i det medeltida samhället. 


\section{Avslutande reflektioner}

Det var den medeltida själavården, med dess betoning av återkommande introspektion och moralisk medvetenhet, som gjorde att samvetet blev en ständig följeslagare i nordbornas inre. I botsakramentet, forum conscientiae, fick man bekanta sig med samvetet som begrepp och fenomen genom att rannsaka det för att finna synder. Det medeltida samhället betonade hierarki och lydnad mot överheten och tanken med samvetspraktiken var naturligtvis inte att den skulle resultera i självständiga eller subjektiva moraliska omdömen. Tvärtom, samvetsgnistan tänktes komma från Gud och bikten vägleddes av en präst som hjälpte biktbarnet identifiera sina synder enligt kyrkans färdiga formulär. Av sådana skäl kan man hävda att samvetet - och inte minst det dåliga samvetet - blev kyrkans instrument för social disciplinering.

Men man kan notera att betoningen av samvetet också kunde få motsatt effekt, och leda till ett ifrågasättande eller rent av trots mot samhällets auktoriteter. För det första var det inte alltid så tydligt hur olika regler skulle omsättas i praktisk handling, vilket ledde till samvetstvivel. Att nå fullständig säkerhet om huruvida ett föreslaget handlingsalternativ var utan risk för synd var inte lätt, och om man endast kunde välja moraliskt riskfria alternativ så kunde det verka förlamande för människor som levde i en värld där bankverksamhet, sexualitet och krig var verklighet. Resultatet blev att kyrkans krav på vad som kunde klassas som moraliskt säkert blev lösare med tiden - Antoninus av Florens godtagande av det moraliskt "säkra" alternativet som lika gott som det moraliskt "säkrare" var ett tecken på denna utveckling. Men vid sidan av en sådan långsam resignation inför svårigheten att fastställa vad samvetet egentligen borde säga så bar själva teorin om samvetet på en mer revolutionär potential. Om samvetet, som teologer likt Thomas av Aquino slog fast, var en oförstörbar gudomlig gnista som i princip inte kunde ta fel (även om det kunde fela i sina specifika tillämpningar), då innebar det också att samvetet i princip var suveränt i förhållande till kyrkliga och världsliga auktoriteter. Teologer och jurister manade till försiktighet 
när det gällde de praktiska konsekvenserna av denna uppfattning. Även om man inte syndade om man till exempel lät bli att betala en orättfärdig skatt så borde man kanske betala ändå, för att undvika samhällsoro. Men i princip så var saken alltså klar: man var tvungen att lyda sitt samvete före kyrkliga och världsliga auktoriteter.

Denna princip om samvetets suveränitet leder oss tillbaka till Botulf som inledde denna artikel, dömd för kätteri i Gottröra socken under 1300-talets början. Man har, med all rätt, uppfattat Botulf som ett offer för kyrkans dogmatism - han straffades ju för att ha ifrågasatt eukaristin som sakrament. Men kanske kan man också se honom som ett offer, eller en företrädare, för den princip om samvetet som även den lärdes ut av kyrkan. Vi vet inte varför Botulf vägrade att avsäga sig sin avvikande uppfattning. Dombrevet som är den enda källan till målet upplyser bara om att han var beredd att genomlida det världsliga straffets tillfälliga eld för att undkomma den eviga elden, fördömelsen. Kanske hade han tagit till sig kyrkans egen idé om samvetet, som lärde att kyrkan förvisso skulle lydas, men att man fick akta så att den lydnaden inte ledde till olydnad mot Gud.

\section{Noter}

1 Fallet beskrivs i det dokument där ärkebiskop Nils redogör för bakgrunden och domen: Svenskt diplomatarium. Stockholm, 1829-, DS 1789. Brevet beskriver Botulfs tvekan inför nattvarden på följande sätt: "et reddens racionem sui dicti immo verius errorem evomens incongruam similitudinem applicando, quod si quis corpus alterius hominis, male sibi redderetsi posset, multo forcius deus [...]." Brevet finns översatt till svenska av Claes Gejrot i Röster från svensk medeltid, utgiven av Hans Aili, Olle Ferm och Helmer Gustavson (Stockholm: Natur och kultur, 1991), s. $112-117$.

2 Oscar Wieselgren, "Botulf från Östby: en inkvisitionsprocess från Sveriges medeltid", Svensk tidskrift 37 (1950), s. 109-118.

3 Bruno Lesch, "En svensk kätteriprocess i början av 1300-talet", Historisk tidskrift för Finland 11 (1926), s. 55-78.

4 Reima Välimäki, "'Hereticum iudicamus': kättardomen över Botulf vid rättegången i Uppsala ärkestift, 1310-1311", Historisk tidskrift för Finland 96:2 (2011), s. 110-130.

5 Gustav Zamore, "A Peripheral Heretic? An Early Fourteenth-Century Heresy Trial from Sweden", Historical Research 93:262 (2020), s. 599-620. 
6 DS (Diplomatarium Suecanum) 1789. "Cumque ipsum in custodia fecissemus detineri, et a quibusdam sibi diceretur, quod si in hoc errore persisteret comburendus esset, ipse in suo errore pertinaciter obduratus, respondit, quod parvo tempore transiret ignis ille $[\ldots]$ ]".

7 Förhållandet mellan samvete och medeltida kyrkliga auktoriteter berörs till exempel i Alexander Murray, "Excommunicationa and Conscience in the Middle Ages", i dennes Conscience and Authority in the Medieval Church, New York: Oxford University Press, 2015, s. 163-197. Murray behandlar resonemang kring plikten att underkasta sig en bannlysning som man uppfattar som felaktig.

8 En introduktion till medeltida lärda uppfattningar om samvetet, som dessutom presenterar omfattande källmaterial i engelsk översättning, ges av Timothy C. Potts, Conscience in Medieval Philosophy, Cambridge: Cambridge University Press, 1980. Thomas av Aquinos uppfattning om samvetet diskuteras mer specifikt i Tobias Hoffman, "Conscience and Synderesis", i Brian Davies \& Eleanor Stump (red.), The Oxford Handbook of Aquinas, New York: Oxford University Press, 2012, s. 255-264.

9 Thomas av Aquino, Questiones disputatae de veritate, utg. A. Dondaine, Editori di san Tommaso, 1972-1976, q. 17: (De Conscientiae) a. 5. co. "[ ...] conscientia recta non solum hoc modo ligat, ut ille qui eam non sequitur peccatum incurrat, sed etiam ut ille qui eam sequitur sit immunis a peccato quantumcumque praeceptum praelati sit in contrarium." Detta för vår fråga centrala avsnitt återges tyvärr inte av Potts.

10 Arnaud Fossier, "Le for de la conscience. L'invention d'une nouvelle frontière juridictionnelle (XIIIe siècle)", i Benoît Garnot och Bruno Lemesle (utg.), La justice entre droit et conscience du XIIIe au XVIIIe siècle, Dijon: Éditions universitaires de Dijon, 2014, s. 115-123.

11 Potts, Conscience, s. 5-7. Med översättningar av relevanta källtexter på s. 78-79, 90-93.

12 Thomas, Questiones, q. 16-17. För översättningar av dessa questiones i utdrag se Potts, Conscience, s. 127-136.

13 Thomas, Questiones, q. 16. a. 2. "Et haec est synderesis, cuius officium est remurmurare malo, et inclinare ad bonum; et ideo concedimus quod in ea peccatum esse non potest. 16. a. 2. ad. 1 [...] synderesis nunquam praecipitatur in universali. Sed in ipsa applicatione universalis principii ad aliquod particulare potest accidere error, propter falsam deductionem, vel alicuius falsi assumptionem." För översättning av questio 16 a. 2 i utdrag se Potts, Conscience, s. 127-129.

14 Thomas, Questiones, q. 16. a. 3. ad 2. "Ad secundum dicendum, quod in haereticis non remurmurat conscientia eorum infidelitati, propter errorem qui est in ratione eorum superiori, ex quo contingit ut synderesis iudicium huic particulari non applicetur. In universali enim iudicium synderesis in eis manet: iudicant enim malum esse non credere his quae a Deo dicuntur; in hoc autem errant secundum rationem superiorem, quod non credunt hoc esse a Deo dictum." För engelsk översättning, se Potts, Conscience, s. 129.

15 Utöver vid fastan tillkom fyra omständigheter som ansågs påkalla behovet av skriftermål: inför risken att dö eller vid annan fara; innan mottagandet av eukaristin eller inför annat sakrament; vid tvivel på att man kommer få tillfälle inför påsken; samt naturligtvis om samvetet krävde det. Se Thomas N. Tentler, Sin and Confession on the Eve of the Reformation, Princeton: Princeton University Press, 2016, s. 73. 
16 Ibid., s. 28-53, presenterar dessa två genrer översiktligt och redogör för populära exempel.

17 Som man kan förvänta sig så innehåller många av samlingshandskrifterna i Vadstena litteratur för att bidra till bikten. Se till exempel Uppsala universitetsbibliotek C72: 2or-47r (Speculum confessorum); 10or-146r (Aureum confessionum/ Ars artium); Uppsala universitetsbibliotek $\mathrm{C}_{73}$ : 114r-141v (Confessionale); 166r-174v (Tractatus de modo et ordine confitendi); 175r-v (Johannes Gerson De modo confessionis sacramentalis).

18 Böckernas ägare kan spåras genom proveniensförteckningarna i Isak Collijn, $\mathrm{Ka}$ talog der Inkunabeln der Kgl. Universitäts-Bibliothek zu Uppsala (Uppsala-Leipzig, 1907), No 124, Antoninus Florentinus, Confessionale (Vadstena klosterbibliotek); No 130, Antoninus Florentinus, Summa theologica P. 4 ("liber swenonis magni" Sven var möjligen kanik i Uppsala); No 131, Antoninus Florentinus, Summa theologica P. 1-4 (Vadstena klosterbibliotek); No 132, Antoninus Florentinus, Summa theologica P. 2-4 ("Frouwe Ingeborg dedit uxor gubernatoris steen stuer [...] liber domus pacis marie in gripzholm" - boken var alltså en donation från Sten Stures hustru Ingeborg till kartusianerna i Mariefred).

19 Enligt Tentler, Sin and Confession, s. 39, trycktes Antoninus olika biktmanualer i över 100 utgåvor och i 32 europeiska städer. 72 av dessa var tryckta i någon form av Confessionale.

20 Antoninus Florentinus, Summa theologica, Basel 1485, p. i, tit. iii, cap. ix. "Sinderesis est quidam connaturalis habitus sive connaturale lumen cuius actus vel officium est hominem detrahere a malo murmurando contra peccatum et inclinare ad bonum".

21 Ibid, p. i, tit. iii, cap. x. \$ ix.

22 Se till exempel Stina Fallberg Sundmark, Teologi för praktiskt bruk: Frälsningshistoriska perspektiv på Summula av Laurentius av Vaksala, Skellefteå: Artos, 2014, s. 142-146.

23 Thomas av Aquino, Summa theologiae, IIa IIae q. 104 a. 5 ad 2. "Ad secundum dicendum quod Deo subiicitur homo simpliciter quantum ad omnia, et interiora et exteriora: et ideo in omnibus ei obedire tenetur. Subditi autem non subiiciuntur suis superioribus quantum ad omnia, sed quantum ad aliqua determinate. Et quantum ad illa, medii sunt inter Deum et subditos. Quantum ad alia vero, immediate subduntur Deo, a quo instruuntur per legem naturalem vel scriptam.” Utdrag ur Thomas behandling av frågor om lydnad återges i engelsk översättning i R. W. Dyson, St Thomas Aquinas: Political Writings, Cambridge: Cambridge University Press, 2002.

24 Thomas redogör för sina kriterier för vad som gör lagen giltig och för olika typer av lag (t. ex. evig lag, naturlig lag och mänsklig lag) och deras förhållande till varandra i Summa theologiae, Ia Ilae q. 90-91. Utdrag ur Thomas diskussion av lagen i Summa återges i engelsk översättning av Dyson, St Thomas Aquinas: Political Writings. Thomas av Aquino, Summa theologiae, Ia Ilae q. 96 a. 4.

26 Ibid.

27 James Franklin, The Science of Conjecture: Evidence and Probability before Pascal, Baltimore: Johns Hopkins University Press, 2001, s. 64-69.

28 Rudolf Schüssler, "Jean Gerson, Moral Certainty and the Renaissance of Ancient Scepticism", i Harald. E. Braun \& Edward Vallance (red.), The Renaissance Conscience, Oxford: Blackwell Publishing, 2011, s. 15-20. Franklin, The Science, s. 69-70. 
29 Antoninus Florentinus, Defecerunt - Confessionale, Venedig 1499, 2r. "Scrutinium quidem est confessio vel inquisitio in quo et penitens scrutatur conscientiam suam, et confessor cum eo".

30 Ibid., 16v. "Oportet ut spiritualis iudex sciat quicquid debet iudicare. [...] ut sciat discernere inter peccatum et non peccatum, et peccatum mortale et veniale, et si in aliquo esset dubitatio sciat dubitare, ut possit ad peritiores recurrere".

31 Ibid., $17 \mathrm{r}-17 \mathrm{v}$. Tumregler till hjälp för att avgöra om en synd är dödlig eller inte presenteras, $27 \mathrm{~V}$.

32 Ibid., 17v-18r. "Caveat autem confessor ne sit praeceps ad dandum sententiam de mortali quando non est certus et clarus. Et ubi in aliqua materia varie opiniones sunt, quamplurium et solennium doctorum, utrum sit licitum vel illicitum, sicut [...] de emptione iurium montis florentie vel imprestitis venetorum, quod quidam dicunt esse usuram alii licitum dicunt, et in multus aliis huiusmodi. Consulat tamen semper quod tutius est, scilicet quod a talibus abstinere [...]. Non tamen condemnet contrarium facientes, seu contrariam opinionem tenentes, nec propter hoc deneget absolutionem."

33 Antoninus, Summa theologica, p. i, tit. iii, cap. x. $\$$ x. Passagen nämns i Franklin, The Science, s. 70.

34 Antoninus, Defecerunt, $18 \mathrm{r}$.

35 Ibid., 16v. "Debet ergo confessor scire discernere inter peccata et differentias peccatorum. Unde scire debet si ea quae exprimit sibi penitentes sint peccata vel non puta an bella principum et ipsorum exactiones sint licita vel ne, et utrum contractus qui fiunt sint liciti vel illiciti."

36 Ibid., 86 r.

37 Ibid., 78r. Jag diskuterar detta frågeformulär för furstar i Biörn Tjällén, "Kungens biktfader: Andlig vägledning och politisk rådgivning vid senmedeltidens hov", Kyrkohistorisk årsskrift (2012), s. 49-59.

38 Antoninus, Summa, p. ii, tit. i, cap. xiii. Jag behandlar frågan om skatter enligt själavården i min artikel "'King bottomless empty purse': taxes, avarice and pastoral care in the Swedish reign of Christian I (1457-64)", Scandinavian Journal of History (2020), s. 1-24.

39 Samvetsfrågan om deltagande respektive ordervägran i "orättfärdiga krig" behandlas kortfattat i Frederick H. Russell, The Just War in the Middle Ages, Cambridge: Cambridge University Press, 1977, s. 226-229.

40 Antoninus Florentinus, Summa teologica, Nürnberg, 1486, p. iii, tit. iiii, cap. ii, § ii, "Item subditus agentis bellum \& in bello eum sequens, si scivit eum habere injustum bellum, quia tunc sequendo non excusatur a peccato, nec a satisfactione damni dati, damnificando ipse per se: sed si post consilium peritorum super hoc remansit dubius de justitita belli; tunc talis est excusatus, quia in dubio debet obedire, sed non excusatur dominus." 